\title{
Paenibacillus tianmuensis sp. nov., isolated from soil
}

\author{
Xuechang Wu, Haihuan Fang, Chaodong Oian, Yanping Wen, \\ Xiaobo Shen, Ou Li and Haichun Gao
}

Correspondence

Xuechang Wu

mblab@163.com

Haichun Gao

haichung@zju.edu.cn
Institute of Microbiology, College of Life Sciences, Zhejiang University, Hangzhou, PR China

Two closely related, Gram-stain-negative, rod-shaped, spore-forming strains, B27 ${ }^{\top}$ and F6-B70, were isolated from soil samples of Tianmu Mountain National Natural Reserve in Zhejiang, China. Phylogenetic analysis based on 16S rRNA gene and rpoB sequences indicated that the isolates were members of the genus Paenibacillus. Both isolates were closely related to Paenibacillus ehimensis IFO $15659^{\top}$, Paenibacillus elgii SD1 $7^{\top}$ and Paenibacillus koreensis ${\text { YC } 300^{\top}}^{\top}$

( $\geqslant 95.2 \% 16 \mathrm{~S}$ rRNA gene sequence similarity). DNA-DNA relatedness between strain $B 27^{\top}$ and $P$. ehimensis DSM $11029^{\top}, P$. elgii NBRC $100335^{\top}$ and $P$. koreensis KCTC $2393^{\top}$ was 21.2, 28.6 and $16.8 \%$, respectively. The major cellular fatty acids of strains B27 ${ }^{\top}$ and F6-B70 were anteiso- $C_{15: 0}$ and iso- $C_{15: 0}$. The cell wall contained meso-diaminopimelic acid. The two isolates differed from their closest neighbours in terms of phenotypic characteristics and cellular fatty acid profiles (such as variable for oxidase, negative for methyl red test, unable to produce acid from D-fructose and glycogen and relatively higher amounts of iso- $C_{15: 0}$ and lower amounts of $C_{16: 0}$ and iso- $\mathrm{C}_{16: 0}$ ). Strains $B 27^{\top}$ and F6-B70 represent a novel species of the genus Paenibacillus, for which the name Paenibacillus tianmuensis sp. nov. is proposed. The type strain is $B 27^{\top}$ $\left(=\mathrm{DSM} 22342^{\top}=\right.$ CGMCC $\left.1.8946^{\top}\right)$.
The genus Paenibacillus was defined by Ash et al. (1991, 1993) after a comparative analysis of $16 \mathrm{~S}$ rRNA gene sequences of group 3 bacilli and then emended by Shida et al. (1997). While the genus included 11 species initially, it comprises more than 110 recognized species at the time of writing (http://www.bacterio.cict.fr/p/paenibacillus.html). Members of the genus Paenibacillus have been one of the hot research topics in recent years because of their ability to produce antifungal and/or antimicrobial compounds. Paenibacillus polymyxa, the type species of the genus Paenibacillus, produces a variety of antibiotics, such as polymyxin A-E, paenibacillin, jolipeptin, gavaserin, saltavalin, fusaricidin A-D and gatavalin (He et al., 2007; Ito \& Koyama, 1972; Kajimura \& Kaneda, 1996, 1997; Katz \& Demain, 1977; Nakajima et al., 1972; Pichard et al., 1995). Paenibacillus koreensis has been reported to produce an iturin-like compound with strong antifungal activity against Fusarium oxysporum, Colletotrichum lagenarium, Sclerotinia sclerotiorum and Botrytis cinerea (Chung et al.,

The GenBank/EMBL/DDBJ accession numbers for the 16S rRNA gene sequences of strains B27 ${ }^{\top}$ and F6-B70 are FJ719490-FJ719492 and GU647099, GQ240305 and GU647100, respectively, and for the rpoB sequences of strains F6-B70, B27 ${ }^{\top}$, Paenibacillus ehimensis DSM $11029^{\top}$, Paenibacillus elgii NBRC $100335^{\top}$ and Paenibacillus koreensis KCTC $2393^{\top}$ are GU979421 and GQ499850-GQ499853, respectively.

Two supplementary figures are available with the online version of this paper.
2000). Paenibacillus elgii also exhibits a broad inhibition spectrum against bacteria and pathogenic fungi (Kim et al., 2004).

Two strains, $\mathrm{B} 27^{\mathrm{T}}$ and F6-B70, were isolated from soil samples collected from Tianmu Mountain National Natural Reserve $\left(30^{\circ} 20^{\prime} \mathrm{N} 119^{\circ} 25^{\prime} \mathrm{E}\right.$; altitude $\left.1200 \mathrm{~m}\right)$, Zhejiang, China. The samples were suspended in sterile distilled water and incubated on nutrient agar $[0.5 \%(\mathrm{w} / \mathrm{v})$ peptone, $0.5 \%(\mathrm{w} / \mathrm{v})$ yeast extract, $0.5 \%(\mathrm{w} / \mathrm{v}) \mathrm{NaCl}, 1.5 \%$ (w/v) agar; $\mathrm{pH} 7.0-7.2]$ at $30{ }^{\circ} \mathrm{C}$ for 3-7 days. Morphologically different colonies were purified by repeated streaking onto nutrient agar. Strain $\mathrm{B} 27^{\mathrm{T}}$ and F6-B70 were routinely cultured at $30{ }^{\circ} \mathrm{C}$ and preserved in glycerol $(20 \%$, $\mathrm{v} / \mathrm{v})$ at $-80{ }^{\circ} \mathrm{C}$. The reference strains Paenibacillus ehimensis DSM $11029^{\mathrm{T}}$, P. elgii NBRC $100335^{\mathrm{T}}$ and $P$. koreensis KCTC $2393^{\mathrm{T}}$ were routinely cultured at $30{ }^{\circ} \mathrm{C}$ on nutrient agar.

Cell morphology and mobility were examined using light microscopy (E600; Nikon), transmission electron microscopy (JEM-1230; JEOL) and scanning electron microscopy (S3000N; Hitachi). Gram staining was carried out by the standard Gram reaction in parallel with the $\mathrm{KOH}$ lysis test (Gregersen, 1978). Growth was tested in basal nutrient broth at $4,10,20,30,37,40,45$ and $50{ }^{\circ} \mathrm{C}$, at $\mathrm{pH} \mathrm{5,} \mathrm{5.6,} \mathrm{6,}$ $7,8,9$ and 10 and with $1-5 \% \mathrm{NaCl}$ (at intervals of $1 \%$ $\mathrm{NaCl}$ ). Anaerobic growth was tested in nutrient broth using Hungate anaerobic culture tubes with nitrogen gas at 
$30{ }^{\circ} \mathrm{C}$. Oxidase and catalase were determined using Kovács' reagent (Kovács, 1956) and 3\% (v/v) hydrogen peroxide, respectively. Acid production from 49 carbon sources was tested using the API $50 \mathrm{CHB}$ system (bioMérieux). Other physiological and biochemical characteristics were determined according to the standard methods described elsewhere (Barrow \& Feltham, 1993; Smibert \& Krieg, 1994). The diamino acid of the peptidoglycan was determined as outlined by Hasegawa et al. (1983). Cellular fatty acids were analysed following the instructions of the Sherlock Microbial Identification System (MIDI) after cultivation on trypticase soy agar (5459; Merck) for $24 \mathrm{~h}$ at $30{ }^{\circ} \mathrm{C}$.

Genomic DNA was extracted and purified according to standard methods (Moore \& Dowhan, 1995). Fragments of the 16S rRNA gene were amplified, cloned into pMD19-T (TaKaRa) and sequenced as described previously ( $\mathrm{Wu}$ et al., 2008). For amplification of almost-complete $r p o B$ sequences from the isolates and the reference strains, three degenerate PCR primer pairs were designed using an alignment of $r p o B$ sequences from Bacillus subtilis $168^{\mathrm{T}}$, Geobacillus kaustophilus HTA 426, Anoxybacillus flavithermus WK1, Escherichia coli K12 and Streptomyces coelicolor A3(2) (GenBank accession numbers AL009126, BA000043, CP000922, CP000948 and AL939121, respectively). The primer pairs were 73F (5'-GAGYTGCCGAACYTGATYGARATYCA-3') and 1584R (5'-RATCAAGCCGATRTTVGGDCCYT-3'), 1429F (5' -TATGCTGARCTBACSCAYAARCG- $\left.3^{\prime}\right)$ and 2177R ( $5^{\prime}$ - TGGTTRTAGCANGTGCCYTGRTT- $\left.3^{\prime}\right)$, and 1876F ( $5^{\prime}$-CGCCCGTTCTTWGAAAAYGAYGAC- $3^{\prime}$ ) and 3306R (5'-GTGGTCGGAYTTRACCGTCAARAT-3'), which correspond to positions (B. subtilis rpoB numbering) 73-99, 1584-1561, 1429-1451, 2177-2155, 1876-1899 and 3306-3283, respectively. The reaction mixture $(50 \mu \mathrm{l}$ final volume) contained $5 \mu \mathrm{l} 10 \times$ PCR buffer, $100 \mu \mathrm{M}$ each dNTP, $500 \mathrm{nM}$ each primer, $1.25 \mathrm{U}$ DNA polymerase (TaKaRa) and $10 \mathrm{ng}$ genomic DNA. Amplification conditions were $95{ }^{\circ} \mathrm{C}$ for $5 \mathrm{~min}, 30$ cycles of $95{ }^{\circ} \mathrm{C}$ for $1 \mathrm{~min}, 60{ }^{\circ} \mathrm{C}\left(56{ }^{\circ} \mathrm{C}\right.$ for primers $1429 \mathrm{~F}$ and 2177R) for $1 \mathrm{~min}$ and $72{ }^{\circ} \mathrm{C}$ for $2 \mathrm{~min}$, and a final extension step at $72{ }^{\circ} \mathrm{C}$ for $7 \mathrm{~min}$. Amplified sequences were cloned into pMD19-T (TaKaRa) and sequenced $(\mathrm{Wu}$ et al., 2008). The partially overlapping sequences were combined into a single consensus sequence using sequence assembler software (Applied Biosystems).

Considering that complete $r p o B$ sequences are not yet available for all of the species of the genus Paenibacillus with validly published names, the phylogenetic analysis used partial $r p o B$ sequences (corresponding to B. subtilis $r p o B$ positions 1571-1934). The sequences obtained in this study and sequences extracted from GenBank were aligned using CLUSTAL W (Thompson et al., 1994) and edited manually. Distances were calculated using distance options according to Kimura's two-parameter model (Kimura, 1980). Phylogenetic trees were reconstructed using the maximum-likelihood (Felsenstein, 1981) algorithm contained in PHYLIP version 3.63 (Felsenstein, 2005) and the neighbour-joining (Saitou \& Nei, 1987) and maximumparsimony (Kluge \& Farris, 1969) algorithms available in MEGA version 4.0 (Tamura et al., 2007). The resultant tree topologies were evaluated by bootstrap analysis based on 100,1000 and 1000 resamplings for the maximumlikelihood, neighbour-joining and maximum-parsimony algorithms, respectively. Determination of DNA G+C content and DNA-DNA hybridization were performed by the thermal denaturation method described by De Ley et al. (1970).

Strains $\mathrm{B} 27^{\mathrm{T}}$ and $\mathrm{F} 6-\mathrm{B} 70$ had similar phenotypic characteristics. Cells were strictly aerobic, stained Gramnegative and also gave a Gram-negative result with the $\mathrm{KOH}$ lysis test. Cells were non-motile rods $(0.75-1.5 \times 3.0-$ $7.5 \mu \mathrm{m}$ ) with no flagella (Supplementary Fig. S1, available in IJSEM Online) and formed ellipsoidal spores that lay terminally or subterminally in swollen sporangia (Supplementary Fig. S2). The isolates were positive for catalase and negative for indole and $\mathrm{H}_{2} \mathrm{~S}$ production. Aesculin, casein, DNA and gelatin were hydrolysed. Oxidase was variable and depended on the growth stage. Other phenotypic characteristics are given in the species description and Table 1. The isolates could be clearly distinguished from the three reference strains by the phenotypic characteristics listed in Table 1, such as oxidase, methyl red test and acid production from different carbon sources. Moreover, the isolates were different from P. ehimensis DSM $11029^{\mathrm{T}}$ and $P$. koreensis $\mathrm{KCTC} 2393^{\mathrm{T}}$ with respect to their inability to grow at $50{ }^{\circ} \mathrm{C}$ and different from P. elgii NBRC $100335^{\mathrm{T}}$ by having no urease activity. Strains B27 $7^{\mathrm{T}}$ and F6-B70 both contained meso-diaminopimelic acid in the cell wall and their DNA G+C contents were 55.4 and $55.5 \mathrm{~mol} \%$, respectively. The isolates also possessed identical cellular fatty acid profiles, with anteiso- $\mathrm{C}_{15: 0}$ and iso- $\mathrm{C}_{15: 0}$ as the major components (Table 2). Distinct quantitative differences were found in the fatty acid profiles of the isolates in comparison with their closest neighbours: for instance, strains $B 27^{\mathrm{T}}$ and $\mathrm{F} 6-\mathrm{B} 70$ contained relatively higher amounts of iso- $\mathrm{C}_{15: 0}$ (22.1 and $18.0 \%$, respectively) and lower amounts of $\mathrm{C}_{16: 0}(1.4$ and $1.8 \%)$ and iso- $\mathrm{C}_{16: 0}(1.2$ and $0.9 \%$ ) than the reference strains (Table 2).

The cloned 16S rRNA genes revealed three types of sequences in strains $\mathrm{B} 27^{\mathrm{T}}$ and $\mathrm{F} 6-\mathrm{B} 70$, indicating intragenomic heterogeneity, which has been found in other species of the genus Paenibacillus (Bosshard et al., 2002; Hamasaki et al., 2005; Nübel et al., 1996; Roux \& Raoult, 2004). Comparative 16S rRNA gene sequence analyses showed that strains $\mathrm{B} 27^{\mathrm{T}}$ and F6-B70 were phylogenetically affiliated to the genus Paenibacillus. Sequences of the same type from strains $\mathrm{B} 27^{\mathrm{T}}$ and F6-B70 exhibited $>99.5 \% 16 \mathrm{~S}$ rRNA gene sequence similarity, which suggested that the isolates are members of the same species. Moreover, the isolates exhibited $99.9 \% \quad r p o B$ sequence similarity (3177 bp) and $70 \%$ DNA-DNA relatedness, which verified that they should be assigned to the same species (Adékambi et al., 2008; Wayne et al., 1987). The maximum-likelihood tree based on 16S rRNA gene sequences (Fig. 1) showed 
Table 1. Differential phenotypic characteristics of strains $B 27^{\top}$ and F6-B70 and closely related type strains of species of the genus Paenibacillus

Strains: 1, Paenibacillus tianmuensis sp. nov. B27 ${ }^{\mathrm{T}}$ and F6-B70; 2, P. ehimensis DSM $11029^{\mathrm{T}}$; 3, P. elgii NBRC $100335^{\mathrm{T}}$; 4, P. koreensis KCTC $2393^{\mathrm{T}}$. All data were taken from this study. All species are positive for catalase, nitrate reduction, $\beta$-galactosidase and hydrolysis of casein, gelatin, aesculin and DNA. All strains are negative for $\mathrm{H}_{2} \mathrm{~S}$ and indole production and citrate utilization. + , Positive; v, variable; w, weakly positive; -, negative.

\begin{tabular}{|c|c|c|c|c|}
\hline Characteristic & 1 & 2 & 3 & 4 \\
\hline Gram-staining & - & $\mathrm{V}$ & $\mathrm{V}$ & $\mathrm{V}$ \\
\hline Oxidase & $\mathrm{V}$ & + & - & + \\
\hline Urease & - & - & + & - \\
\hline Methyl red test & - & + & + & + \\
\hline \multicolumn{5}{|l|}{ Growth at/with: } \\
\hline $50{ }^{\circ} \mathrm{C}$ & - & + & - & + \\
\hline pH 5.6 & - & - & $-*$ & + \\
\hline \multicolumn{5}{|l|}{ Acid production from: } \\
\hline L-Arabinose & - & + & - & + \\
\hline D-Fructose & - & + & $\mathrm{w}$ & + \\
\hline D-Mannose & - & + & $-{ }^{\star}$ & + \\
\hline Inositol & - & + & - & + \\
\hline Mannitol & - & + & - & + \\
\hline Sorbitol & - & + & - & + \\
\hline Methyl $\alpha$-D-mannoside & - & $\mathrm{w}$ & - & + \\
\hline Methyl $\alpha$-D-glucoside & + & + & - & + \\
\hline Amygdalin & - & + & - & $+\dagger$ \\
\hline Arbutin & - & + & - & + \\
\hline Salicin & - & + & - & $+\dagger$ \\
\hline Cellobiose & $\mathrm{w}$ & + & - & + \\
\hline Lactose & - & + & - & + \\
\hline Melibiose & - & + & - & + \\
\hline Melezitose & - & + & - & - \\
\hline Raffinose & - & + & - & + \\
\hline Starch & $\mathrm{w}$ & + & + & + \\
\hline Glycogen & - & + & + & + \\
\hline Xylitol & + & - & - & - \\
\hline D-Gentiobiose & $\mathrm{w}$ & + & - & + \\
\hline D-Arabitol & - & + & - & + \\
\hline
\end{tabular}

${ }^{*}$ Data differ from those obtained by Kim et al. (2004).

$\dagger$ Data differ from those obtained by Chung et al. (2000).

that strains $\mathrm{B} 27^{\mathrm{T}}$ and $\mathrm{F} 6-\mathrm{B} 70$ were closely related to $P$. ehimensis IFO $15659^{\mathrm{T}}, P$. elgii $\mathrm{SD} 17^{\mathrm{T}}$ and $P$. koreensis $\mathrm{YC}_{0} 00^{\mathrm{T}}$, with which strain $\mathrm{B} 27^{\mathrm{T}}$ shared $96.0-97.2$, 95.897.1 and $95.2-96.3 \% 16 \mathrm{~S}$ rRNA gene sequence similarity, respectively. The phylogenetic trees inferred with the neighbour-joining and maximum-parsimony algorithms showed relationships similar to those inferred with the maximum-likelihood algorithm.

To further validate the phylogenetic affinity of the isolates, this study analysed sequences of the $r p o B$ gene, which has been shown to be more discriminative than the 16S rRNA gene in distinguishing members of the genus Paenibacillus
Table 2. Cellular fatty acid profiles of strains $B 27^{\top}$ and F6-B70 and closely related type strains of species of the genus Paenibacillus

Strains: 1, Paenibacillus tianmuensis sp. nov. $\mathrm{B} 27^{\mathrm{T}} ; 2$, P. tianmuensis sp. nov. F6-B70; 3, P. ehimensis DSM $11029^{\mathrm{T}}$; 4, P. elgii NBRC $100335^{\mathrm{T}} ; 5$, P. koreensis KCTC $2393^{\mathrm{T}}$. All data were taken from this study. - , Not detected.

\begin{tabular}{|lccccc|}
\hline Fatty acid (\%) & $\mathbf{1}$ & $\mathbf{2}$ & $\mathbf{3}$ & $\mathbf{4}$ & $\mathbf{5}$ \\
\hline Saturated & & & & & \\
$\quad \mathrm{C}_{14: 0}$ & 1.0 & 0.9 & 0.8 & 2.3 & 1.2 \\
$\mathrm{C}_{16: 0}$ & 1.4 & 1.8 & 3.2 & 7.6 & 9.5 \\
Branched & & & & & \\
$\quad$ iso-C $14: 0$ & 0.9 & 0.6 & 2.5 & 2.3 & 2.7 \\
$\quad$ iso- $\mathrm{C}_{15: 0}$ & 22.1 & 18.0 & 10.6 & 10.7 & 7.0 \\
anteiso-C $15: 0$ & 58.1 & 58.2 & 53.9 & 51.8 & 44.5 \\
iso-C $16: 0$ & 1.2 & 0.9 & 9.5 & 6.0 & 14.4 \\
iso-C $17: 0$ & 2.8 & 3.3 & 3.1 & 2.8 & 3.9 \\
$\quad$ anteiso-C $17: 0$ & 4.8 & 7.6 & 6.8 & 5.5 & 8.5 \\
Unsaturated & & & & & \\
$\quad \mathrm{C}_{16: 1} \omega 7 c$ alcohol & 0.9 & 0.7 & 2.6 & 1.6 & 1.5 \\
$\mathrm{C}_{16: 1} \omega 11 c$ & 3.2 & 3.5 & 4.5 & 5.4 & 5.1 \\
$\quad$ iso-C $17: 1 \omega 10 c$ & 2.2 & 2.3 & 1.3 & 1.1 & 0.6 \\
Summed feature $4 *$ & 1.4 & 2.3 & 0.8 & - & 0.5 \\
\hline
\end{tabular}

* Summed features represent two or three fatty acids that cannot be separated by the Microbial Identification System. Summed feature 4 consisted of iso- $\mathrm{C}_{17: 1} \mathrm{I}$ and/or anteiso- $\mathrm{C}_{17: 1} \mathrm{~B}$.

(da Mota et al., 2004). The maximum-likelihood tree based on partial $r p o B$ gene sequences (Fig. 2) showed that strains $\mathrm{B} 27^{\mathrm{T}}$ and F6-B70 fell within the cluster comprising the genus Paenibacillus and formed a separate lineage within the $P$. ehimensis $-P$. koreensis $-P$. elgii cluster. The overall partial $r p o B$ gene sequence similarity between strain $\mathrm{B} 27^{\mathrm{T}}$ and members of the genus Paenibacillus was $71.3-94.8 \%$. The almost-complete $r p o B$ gene sequence similarities between strain $\mathrm{B} 27^{\mathrm{T}}$ and $P$. ehimensis DSM $11029^{\mathrm{T}}, P$. koreensis KCTC $2393^{\mathrm{T}}$ and $P$. elgii NBRC $100335^{\mathrm{T}}$ were 95.3, 95.2 and $94.4 \%$, respectively, which were quite similar to the partial $r p o B$ gene sequence similarities (94.8, 94.2 and $90.1 \%$, respectively). All rpoB gene sequence similarities were below the $97.7 \%$ cut-off value suggested for the genomic distinction of species (Adékambi et al., 2008) and indicated that strain $\mathrm{B} 27^{\mathrm{T}}$ represented a novel species of the genus Paenibacillus.

DNA-DNA relatedness between strain $B 27^{\mathrm{T}}$ and $P$. ehimensis DSM $11029^{\mathrm{T}}$, P. elgii NBRC $100335^{\mathrm{T}}$ and $P$. koreensis KCTC $2393^{\mathrm{T}}$ was 21.2, 28.6 and $16.8 \%$, respectively, which further verified that strains $B 27^{\mathrm{T}}$ and F6-B70 belong to a novel species of the genus Paenibacillus (Wayne et al., 1987).

Therefore, on the basis of phenotypic, genotypic and chemotaxonomic data, strains $\mathrm{B} 27^{\mathrm{T}}$ and F6-B70 represent a novel species of the genus Paenibacillus, for which the name Paenibacillus tianmuensis sp. nov. is proposed. 




Fig. 1. Maximum-likelihood tree based on 16S rRNA gene sequences showing the phylogenetic position of Paenibacillus tianmuensis sp. nov. within the genus Paenibacillus. Bootstrap values ( $>50 \%)$ based on 100 resamplings are shown at branch nodes. Filled circles indicate that corresponding nodes were also recovered in trees generated with the neighbour-joining and maximum-parsimony algorithms. Brevibacillus brevis DSM $30^{\top}$ was used as an outgroup. Bar, 0.01 substitutions per nucleotide position.

\section{Description of Paenibacillus tianmuensis sp. nov.}

Paenibacillus tianmuensis (ti.an.mu.en'sis. N.L. masc. adj. Tianmuensis pertaining to Tianmu Mountain National Natural Reserve in Zhejiang Province, China, where the type strain was isolated).

The species description is based on two strains. Cells are strictly aerobic, Gram-stain-negative, non-motile rods (0.75$1.5 \times 3.0-7.5 \mu \mathrm{m})$. No flagella are observed. Ellipsoidal spores are formed at terminal or subterminal positions in swollen sporangia. After $48 \mathrm{~h}$ on nutrient agar at $30{ }^{\circ} \mathrm{C}$,

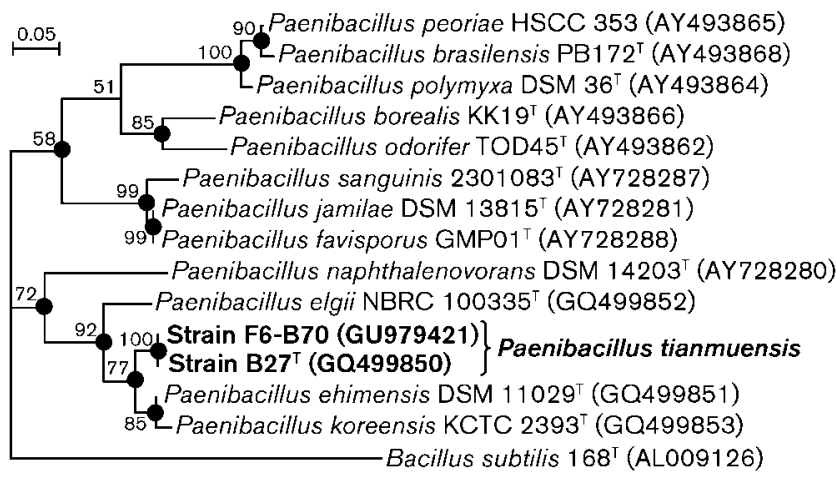

Fig. 2. Maximum-likelihood tree based on partial rpoB sequences showing the phylogenetic position of Paenibacillus tianmuensis sp. nov. within the genus Paenibacillus. Bootstrap values (>50\%) based on 100 resamplings are shown at branch nodes. Filled circles indicate that corresponding nodes were also recovered in trees generated with the neighbour-joining and maximumparsimony algorithms. Bacillus subtilis $168^{\top}$ was used as an outgroup. Bar, 0.05 substitutions per nucleotide position. colonies are $1-2 \mathrm{~mm}$ in diameter, circular, flat, glossy, translucent and pale yellow. Growth occurs at $20-37^{\circ} \mathrm{C}$, at $\mathrm{pH}$ 6-8 and with $0-2 \%(\mathrm{w} / \mathrm{v}) \mathrm{NaCl}$. Optimum growth occurs at $30{ }^{\circ} \mathrm{C}$ and $\mathrm{pH}$ 7. Oxidase is variable, depending on the growth stage. Positive for catalase, $\beta$-galactosidase and nitrate reduction. Negative for urease, indole and $\mathrm{H}_{2} \mathrm{~S}$ production, Voges-Proskauer test, methyl red test and citrate utilization. Aesculin, casein, DNA and gelatin are hydrolysed and starch is weakly hydrolysed. Acid is produced from D-ribose, D-galactose, D-glucose, methyl $\alpha$-D-glucoside, $\mathrm{N}$-acetylglucosamine, aesculin, maltose, sucrose, trehalose, xylitol and turanose. Acid is weakly produced from glycerol, cellobiose, starch and gentiobiose. Acid is not produced from erythritol, D-arabinose, L-arabinose, D-xylose, L-xylose, $\mathrm{D}$-adonitol, methyl $\beta$-D-xyloside, D-fructose, D-mannose, L-sorbose, L-rhamnose, dulcitol, inositol, D-mannitol, D-sorbitol, methyl $\alpha$-D-mannoside, amygdalin, arbutin, salicin, lactose, melibiose, inulin, melezitose, raffinose, glycogen, D-lyxose, D-tagatose, D-fucose, L-fucose, D-arabitol, L-arabitol, gluconate, 2-ketogluconate or 5-ketogluconate. The major fatty acids are anteiso- $\mathrm{C}_{15: 0}$ and iso- $\mathrm{C}_{15: 0}$. The diamino acid in the cell wall is meso-diaminopimelic acid. The DNA G + C content of the type strain is $55.4-55.5 \mathrm{~mol} \%$.

The type strain, B27 $\left(=\right.$ DSM $22342^{\mathrm{T}}=$ CGMCC $\left.1.8946^{\mathrm{T}}\right)$, was isolated from soil of Tianmu Mountain National Natural Reserve in Zhejiang, China.

\section{Acknowledgements}

This study was financially supported by Major Program of Science and Technology Department of Zhejiang (grant number 2009C12061). We would like to acknowledge Shu-Zhen Yang and Ming-Shui Zhao of Tianmu Mountain National Natural Reserve for sample collection and Wei-Feng Chen for his assistance in the strain isolation. 


\section{References}

Adékambi, T., Shinnick, T. M., Raoult, D. \& Drancourt, M. (2008). Complete $r p o B$ gene sequencing as a suitable supplement to DNADNA hybridization for bacterial species and genus delineation. Int $J$ Syst Evol Microbiol 58, 1807-1814.

Ash, C., Farrow, J. A. E., Wallbanks, S. \& Collins, M. D. (1991). Phylogenetic heterogeneity of the genus Bacillus revealed by comparative analysis of small subunit ribosomal RNA sequences. Lett Appl Microbiol 13, 202-206.

Ash, C., Priest, F. G. \& Collins, M. D. (1993). Molecular identification of rRNA group 3 bacilli (Ash, Farrow, Wallbanks and Collins) using a PCR probe test. Proposal for the creation of a new genus Paenibacillus. Antonie van Leeuwenhoek 64, 253-260.

Barrow, G. I. \& Feltham, R. K. A. (editors) (1993). Cowan and Steel's Manual for the Identification of Medical Bacteria, 3rd edn. Cambridge: Cambridge University Press.

Bosshard, P. P., Zbinden, R. \& Altwegg, M. (2002). Paenibacillus turicensis sp. nov., a novel bacterium harbouring heterogeneities between $16 S$ rRNA genes. Int J Syst Evol Microbiol 52, 2241-2249.

Chung, Y. R., Kim, C. H., Hwang, I. \& Chun, J. (2000). Paenibacillus koreensis sp. nov., a new species that produces an iturin-like antifungal compound. Int J Syst Evol Microbiol 50, 1495-1500.

da Mota, F. F., Gomes, E. A., Paiva, E., Rosado, A. S. \& Seldin, L. (2004). Use of $r p o B$ gene analysis for identification of nitrogen-fixing Paenibacillus species as an alternative to the 16S rRNA gene. Lett Appl Microbiol 39, 34-40.

De Ley, J., Cattoir, H. \& Reynaerts, A. (1970). The quantitative measurement of DNA hybridization from renaturation rates. Eur $J$ Biochem 12, 133-142.

Felsenstein, J. (1981). Evolutionary trees from DNA sequences: a maximum likelihood approach. J Mol Evol 17, 368-376.

Felsenstein, J. (2005). PHYLIP (phylogeny inference package) version 3.63. Distributed by the author. Department of Genome Sciences, University of Washington, Seattle, USA.

Gregersen, T. (1978). Rapid method for distinction of Gram-negative from Gram-positive bacteria. Eur J Appl Microbiol Biotechnol 5, 123 127.

Hamasaki, Y., Watanabe, Y., Kotoura, S., Fuchu, H., Sugiyama, M., Hashizume, K. \& Morita, H. (2005). Paenibacillus macerans possesses two types of $16 \mathrm{~S}$ rDNA copies in a genome with a length difference of twelve base pairs. Biosci Biotechnol Biochem 69, 1995-1998.

Hasegawa, T., Takizawa, M. \& Tanida, S. (1983). A rapid analysis for chemical grouping of aerobic actinomycetes. J Gen Appl Microbiol 29, 319-322.

He, Z. G., Kisla, D., Zhang, L. W., Yuan, C. H., Green-Church, K. B. \& Yousef, A. E. (2007). Isolation and identification of a Paenibacillus polymyxa strain that coproduces a novel lantibiotic and polymyxin. Appl Environ Microbiol 73, 168-178.

Ito, M. \& Koyama, Y. (1972). Jokipeptin, a new peptide antibiotic. I. Isolation, physico-chemical and biological characteristics. J Antibiot (Tokyo) 25, 304-308.

Kajimura, Y. \& Kaneda, M. (1996). Fusaricidin A, a new depsipeptide antibiotic produced by Bacillus polymyxa KT-8. Taxonomy, fermentation, isolation, structure elucidation and biological activity. J Antibiot (Tokyo) 49, 129-135.

Kajimura, Y. \& Kaneda, M. (1997). Fusaricidins B, C and D, new depsipeptide antibiotics produced by Bacillus polymyxa KT-8: isolation, structure elucidation and biological activity. J Antibiot (Tokyo) 50, 220-228.
Katz, E. \& Demain, A. L. (1977). The peptide antibiotics of Bacillus: chemistry, biogenesis, and possible functions. Bacteriol Rev 41, 449474 .

Kim, D.-S., Bae, C.-Y., Jeon, J.-J., Chun, S.-J., Oh, H. W., Hong, S. G., Baek, K.-S., Moon, E. Y. \& Bae, K. S. (2004). Paenibacillus elgii sp. nov., with broad antimicrobial activity. Int J Syst Evol Microbiol 54, 2031-2035.

Kimura, M. (1980). A simple method for estimating evolutionary rates of base substitutions through comparative studies of nucleotide sequences. J Mol Evol 16, 111-120.

Kluge, A. G. \& Farris, J. S. (1969). Quantitative phyletics and the evolution of anurans. Syst Zool 18, 1-32.

Kovács, N. (1956). Identification of Pseudomonas pyocyanea by the oxidase reaction. Nature 178, 703.

Moore, D. D. \& Dowhan, D. (1995). Preparation and analysis of DNA. In Current Protocols in Molecular Biology, pp. 2-11. Edited by F. M. Ausubel, R. Brent, R. E. Kingston, D. D. Moore, J. G. Seidman, J. A. Smith \& K. Struhl. New York: Wiley.

Nakajima, N., Chihara, S. \& Koyama, Y. (1972). A new antibiotic, gatavalin. I. Isolation and characterization. J Antibiot (Tokyo) 25, 243-247.

Nübel, U., Engelen, B., Felske, A., Snaidr, J., Wieshuber, A., Amann, R. I., Ludwig, W. \& Backhaus, H. (1996). Sequence heterogeneities of genes encoding $16 \mathrm{~S}$ rRNAs in Paenibacillus polymyxa detected by temperature gradient gel electrophoresis. J Bacteriol 178, 56365643.

Pichard, B., Larue, J. P. \& Thouvenot, D. (1995). Gavaserin and saltavalin, new peptide antibiotics produced by Bacillus polymyxa. FEMS Microbiol Lett 133, 215-218.

Roux, V. \& Raoult, D. (2004). Paenibacillus massiliensis sp. nov., Paenibacillus sanguinis sp. nov. and Paenibacillus timonensis sp. nov., isolated from blood cultures. Int J Syst Evol Microbiol 54, 1049-1054.

Saitou, N. \& Nei, M. (1987). The neighbor-joining method: a new method for reconstructing phylogenetic trees. Mol Biol Evol 4, 406425.

Shida, O., Takagi, H., Kadowaki, K., Nakamura, L. K. \& Komagata, K. (1997). Emended description of Paenibacillus amylolyticus and description of Paenibacillus illinoisensis sp. nov. and Paenibacillus chibensis sp. nov. Int J Syst Bacteriol 47, 299-306.

Smibert, R. M. \& Krieg, N. R. (1994). Phenotypic characterization. In Methods for General and Molecular Bacteriology, pp. 607-654. Edited by P. Gerhardt, R. G. E. Murray, W. A. Wood \& N. R. Krieg. Washington, DC: American Society for Microbiology.

Tamura, K., Dudley, J., Nei, M. \& Kumar, S. (2007). MEGA4: molecular evolutionary genetics analysis (MEGA) software version 4.0. Mol Biol Evol 24, 1596-1599.

Thompson, J. D., Higgins, D. G. \& Gibson, T. J. (1994). CLUSTAL W: improving the sensitivity of progressive multiple sequence alignment through sequence weighting, position-specific gap penalties and weight matrix choice. Nucleic Acids Res 22, 4673-4680.

Wayne, L. G., Brenner, D. J., Colwell, R. R., Grimont, P. A. D., Kandler, O., Krichevsky, M. I., Moore, L. H., Moore, W. E. C., Murray, R. G. E. \& other authors (1987). International Committee on Systematic Bacteriology. Report of the ad hoc committee on reconciliation of approaches to bacterial systematics. Int J Syst Bacteriol 37, 463-464.

Wu, X., Wen, Y., Qian, C., Li, O., Fang, H. \& Chen, W. (2008). Taxonomic study of a chromomycin-producing strain and reclassification of Streptomyces cavourensis subsp. washingtonensis as a later synonym of Streptomyces griseus. Int J Syst Evol Microbiol 58, 2783-2787. 